\title{
Efek Pembingkaian Terhadap Keputusan Berisiko Ditinjau dari Teori Prospek dan Teori Fuzzy-Trace
}

\author{
Afida Sabrina Syifa* \\ Departemen Psikologi Kepribadian dan Sosial, Fakultas Psikologi Universitas Airlangga
}

\begin{abstract}
ABSTRAK
Risky choice framing adalah salah satu jenis framing yang mencoba mengubah persepsi seseorang dengan melakukan presentasi informasi berdasarkan untung dan rugi. Efek risky choice framing dapat memiliki efek terhadap pembuatan keputusan berisiko. Efek ini dijelaskan menggunakan teori prospek dan teori fuzzy-trace. Kedua jenis teori tersebut memiliki pendekatan yang berbeda dalam menjelaskan risky choice framing. Teori prospek menggunakan pendekatan tradisional dengan mempertimbangkan kombinasi antara kemungkinan hasil yang akan didapatkan. Teori fuzzy-trace menjelaskan proses berpikir yang mengarah pada proses berpikir intuitif dalam memproses sebuah informasi. Hasil eksperimen menunjukkan tidak adanya pengaruh perlakuan eksperimen terhadap pembuatan keputusan berisiko. Hal ini dimungkinkan terjadi karena skenario cerita yang digunakan pada proses eksperimen kurang efektif dalam menyampaikan efek untung dan rugi secara general kepada semua partisipan.
\end{abstract}

Kata kunci: keputusan berisiko, risky choice framing, teori fuzzy trace, teori prospek

\begin{abstract}
Risky choice framing is one of the type of framing to change person's perception by presenting information based on profit and loss. Framing options at risky effect can have an effect on making risky decisions. This effect is explained by prospect theory and fuzzy-trace theory. These theories have different approaches in explaining risky choice framing. Prospect theory use traditional approach by considering the possible results that will be obtained. Fuzzy-trace theory explains cognitive approach that leads to intuitive approach to process information. The results of this study indicated that the given intervention has no effects on risky decision making. This occurs because the scenarios used in experimental process are less effective in conveying the effects in all participants.
\end{abstract}

Keywords: fuzzy trace theory, prospect theory, risky choice framing, risk decisions

Buletin Penelitian Psikologi dan Kesehatan Mental (BRPKM), 2021, Vol. 1(1), 302-316

*Alamat korespondensi: Fakultas Psikologi Universitas Airlangga, Kampus B Universitas Airlangga Jalan Airlangga 4-6 Surabaya 60286. Surel: afida.sabrina.syifa-2017@psikologi.unair.ac.id 


\section{PEN D A H U L U A N}

Membuat keputusan adalah kegiatan yang seringkali kita lakukan dalam kehidupan sehari-hari setelah mempertimbangkan kemungkinan yang ada. Proses pertimbangan ini dilakukan untuk menghindari resiko dan kerugian. Namun, beberapa keputusan seringkali dibuat dengan mengesampingkan resiko yang ada. Keputusan berisiko dapat dijelaskan sebagai suatu kegiatan membuat keputusan berdasarkan spekulasi dengan kemungkinan yang telah diketahui sebelumnya (Kahneman, 1991). Kemungkinan spekulatif yang terjadi di masa depan bisa disebut sebagai gambling (Kahneman \& Tversky, 1979). Penilaian seseorang mengenai hal-hal apa saja yang dipandang memiliki konsekuensi buruk dibentuk oleh adanya persepsi (Grichnik, 2008). Persepsi inilah yang akan mempengaruhi sebuah keputusan.

Keputusan-keputusan berisiko seringkali ditemukan dalam bidang medis (Hellinger, 1989). Hasil pengobatan yang diberikan oleh seorang dokter mengandung kemungkinan-kemungkinan yang membuat pasien harus mengambil keputusan secara gambling. Hal ini dikarenakan efek setiap pengobatan yang diberikan tidak dapat diketahui secara pasti. Keputusan dalam bidang kesehatan adalah keputusan yang paling banyak melibatkan resiko daripada persoalan di bidang lain (Kühberger, 1998). Keputusan berisiko ditemui pada kebiasaan seseorang dalam mengkonsumsi makanan yang tidak sehat (Lusk \& Coble, 2005). Keputusan berisiko juga dibuat ketika mengkonsumsi rokok, alkohol, dan tidak menggunakan sabuk pengaman (Anderson \& Mellor, 2008).

Seseorang akan memilih keputusan berisiko apabila hasil akhir berasosiasi dengan kerugian, namun ia akan menghindari sebuah resiko apabila hasil akhir berasosiasi dengan keuntungan (Tversky \& Kahneman, 1981). Hal ini terjadi karena adanya loss aversion. Loss aversion dikenal sebagai kecenderungan seseorang untuk menilai sebuah kehilangan lebih besar dari yang sesungguhnya (Kahneman \& Tversky, 1979). Pengambilan keputusan berisiko dipengaruhi oleh konteks (tingkat kemungkinan), aksebilitas terhadap konten (memori dan emosi), karakteristik pengambil keputusan (seperti kognitif dan motivasi), dan presentasi dari sebuah masalah (Kusev \& van Schaik, 2011). Sebuah keputusan yang diambil tidak lagi dipengaruhi oleh usaha memaksimalkan keuntungan seperti yang dijelaskan pada teori normatif (Repetto dkk., 2017).

Keputusan seseorang untuk mengambil keputusan berisiko dapat disebabkan oleh beberapa faktor. Faktor pertama adalah umur. Bertambahnya umur membuat seseorang memiliki kuantitas pembuatan keputusan berisiko yang lebih rendah (Gardner \& Steinberg, 2005). Orang tua cenderung menghidari resiko yang berhubungan dengan kerugian daripada seseorang yang berusia lebih muda (Albert \& Duffy, 2012). Remaja menunjukkan tingkat pengambilan keputusan berisiko yang lebih banyak dibandingkan orang dewasa (Steinberg, 2006). Perbedaan intensitas pengambilan keputusan berisiko disebabkan karena semakin bertambah umur, di mana pengambilan keputusan tersebut berasosiasi dengan semakin meningkat pula kemampuan untuk mengontrol diri. Perilaku ini berkaitan dengan perubahan otak pada bagian kontrol sistem kognitif yang berhubungan dengan perbaikan kemampuan individu dalam melakukan regulasi diri (Steinberg, 2006).

Faktor kedua adalah teman sebaya. Seseorang akan rela membuat keputusan berisiko untuk mendapatkan keuntungan yang melebihi orang lain (Linde \& Sonnemans, 2012). Hal ini muncul karena adanya perbandingan sosial (Tomova \& Pessoa, 2018). Akibatnya seseorang akan lebih banyak membuat keputusan berisiko apabila mereka sedang bersama dengan teman sebaya (Gardner \& Steinberg, 2005).

Faktor ketiga adalah faktor kognitif. Seseorang dengan kemampuan kognitif yang rendah cenderung menghindari resiko daripada orang dengan kemampuan kognitif yang lebih tinggi (Park, 2016). 
Kesimpulan ini didapat dari perilaku investor dalam memandang sebuah resiko investasi. Investor dengan kemampuan kognitif yang rendah lebih memilih aset dengan kemungkinan resiko yang kecil atau bahkan aset yang tidak memiliki kemungkinan untuk merugi.

Faktor terakhir adalah framing. Framing dalam penelitian Tversky \& Kahneman (1981) diartikan sebagai perbedaan preferensi yang diakibatkan oleh perbedaan kata yang digunakan untuk mendeskripsikan masalah yang sama. Framing dapat dilakukan dengan menambahkan, mengurangi, atau mengganti penggunaan kata pada deskripsi permasalahan. Harapannya dengan melakukan hal tersebut, seseorang akan mengalami kesulitan untuk menemukan kesetaraan dalam dua opsi yang sama.

Framing disajikan menggunakan kata yang memiliki makna positif dan negatif. Pada framing positif, sebuah keputusan akan dilihat memberikan keuntungan (gain) sementara pada framing negatif sebuah keputusan akan dilihat sebagai sebuah kerugian (loss) (Tversky \& Kahneman, 1981). Konsep untung dan rugi dibentuk dari deskripsi yang diberikan dan mempengaruhi persepsi seseorang dalam memandang sebuah masalah (Rothman dkk., 1997). Dalam masalah tersebut, seseorang akan dihadapkan pada dua pilihan yaitu 1) pilihan yang terkesan memberikan keuntungan dan 2) yang memberikan kerugian. Framing berperan mengubah persepsi untung dan rugi tersebut. Framing juga disajikan dengan mengkombinasikan pilihan berisiko (risk) dan tidak berisiko (sure). Efek framing tidak akan terlihat apabila pilihan sure dan risk dipresentasikan dengan porsi yang seimbang (Kühberger \& Tanner, 2010). Pilihan sure dinilai memiliki efek yang lebih kuat dibanding opsi pilihan risk sehingga perubahan-perubahan yang diberikan pada pilihan ini berpotensi menghilangkan efek framing.

Berdasarkan objek framing, tujuan framing, dan bagaimana framing diukur; maka framing dapat dibedakan menjadi tiga macam yaitu risky choice framing, attribute framing, dan goal framing (Levin dkk., 1998). Levin dkk (1998) mengkategorikan framing yang digunakan dalam penelitian Tversky \& Kahneman (1981) sebagai risky choice framing. Attribute framing dapat dilihat dari pemilihan kata yang digunakan sebagai predikat dalam sebuah kalimat (Fisher, 2020). Contohnya pada kalimat "seorang pemain bola basket berhasil memasukkan bola dengan persentase 60 persen akan dipersepsikan memiliki makna yang berbeda dengan kalimat "seorang pemain bola basket gagal memasukkan bola basket dengan persentase 40 persen". Framing atribut membuktikan apabila peran suatu kata memiliki makna yang besar. Dalam teori ini, penggunaan suatu kata sering dikenal dengan sebutan label. Label "berlemak" dan "tidak berlemak" pada sebuah kalimat akan membuat pembeli memilih burger dengan label "75 persen tidak berlemak" daripada burger dengan label "25 persen lemak". Hal tersebut terjadi karena "lemak" diasosiasikan sebagai hal yang kurang baik dalam gaya hidup seseorang. Seseorang juga akan lebih memiliki sikap positif terhadap proses medis dengan pemberian label "tingkat kelangsungan hidup" daripada "tingkat kematian" (Hardisty dkk., 2010).

Goal framing melihat suatu hal berdasarkan ada atau tidaknya perilaku yang berhubungan dengan tercapainya atau tidak tercapainya suatu tujuan. Misalnya, seorang dokter mengatakan kepada pasien bahwa melakukan mammogram dapat mendatangkan keuntungan karena bisa mendeteksi dini kanker payudara. Pernyataan tersebut berusaha menunjukkan hubungan antara perilaku dengan tujuan seseorang yaitu melakukan deteksi dini pada kanker (Krishnamurthy dkk., 2001). Dalam goal framing, peningkatan kemungkinan untuk terkena penyakit dianggap sebagai sebuah kerugian sementara penurunan kemungkinan untuk terkena penyakit dilihat sebagai sebuah keuntungan. Maka dari itu, seseorang akan rela mengikuti nasihat dokter ketika hal tersebut diikuti dengan akibat dari ketidakpatuhan (Peng dkk., 2013). Dalam hal ini, framing negatif (kerugian) memiliki efek yang lebih efektif daripada framing positif (keuntungan). 
Perbedaan dari risky choice framing, attribute framing, dan goals framing adalah risky choice framing cocok digunakan pada konteks keputusan berisiko sedangkan jenis framing yang lain digunakan pada keputusan tidak berisiko. Oleh karena itu, penelitian ini menggunakan risky choice framing dibanding jenis framing yang lain. Manipulasi risky choice framing dilakukan dengan menggunakan sebuah skenario yang diikuti dengan pemberian pilihan-pilihan didalamnya. Pilihan yang diberikan, sebelumnya telah dimanipulasi dengan mengkombinasikan pilihan tidak berisiko (sure choices), pilihan berisiko (risky choices), positive framing, dan negative framing. Pilihan berisiko biasanya disertai dengan kemungkinan numerikal serta pengunaan kata 'semua' atau 'tidak sama sekali' untuk menggambarkan kemungkinan suatu kejadian (Levin dkk., 1998).

Tiga faktor penting yang mempengaruhi efek framing adalah penggunaan skenario masalah, kriteria untung dan rugi dalam sebuah keputusan dan positive framing serta negative framing (Fagley \& Miller, 1987). Penggunaan skenario atau manipulasi konteks masalah dapat memberikan perbedaan efek. Sebuah penelitian eksperimen menunjukkan adanya efek framing pada skenario masalah kesehatan dan masalah lingkungan dibandingkan pada skenario masalah keuangan (Heilman \& Miclea, 2016). Penelitian lain juga mengungkapkan hal serupa, dimana masalah yang melibatkan kehidupan langsung manusia memiliki efek framing yang lebih besar daripada masalah bisnis, sosial, ataupun binatang (Kühberger, 1998). Keberhasilan framing juga ditentukan oleh partisipan yang akan membuat keputusan. Seseorang yang lebih netral dalam memandang resiko akan lebih susah untuk terjerat dalam efek framing (Fagley \& Miller, 1990).

Risky choice framing dalam penelitian ini dijelaskan menggunakan teori prospek dan fuzzy-trace. Teori prospek menjelaskan apabila seseorang rela mengambil resiko ketika sebuah pilihan memiliki kemungkinan mendatangkan kerugian (Rothman dkk., 1997). Seseorang rela mengambil keputusan berisiko untuk kehilangan yang besar demi mencegah beberapa kerugian. Ekspektasi mengenai efek kerugian berlaku convex artinya semakin tidak menguntungan sebuah pilihan, maka semakin besar persepsi kerugian yang akan didapatkan. Efek keuntungan memberikan efek concave atau setiap peningkatan keuntungan yang diperoleh dipersepsikan memiliki peningkatan yang kecil.

Teori fuzzy-trace terinspirasi dari penelitian mengenai memori dan pikiran. Riset menyebutkan adanya independensi antara pikiran dan memori. Dalam proses pembuatan keputusan, seseorang akan membuat dua representasi mental yaitu gist dan verbatim (Reyna, 2004). Representasi gist bersifat fuzzy (kurang tepat) dibandingkan verbatim. Gist bekerja dengan cara menyederhanakan informasi kuantitatif yang tersedia ke dalam penilaian kualitatif. Contoh dari reduksi informasi ini adalah pada kalimat: 1) "200 orang akan selamat" akan dipahami menjadi "beberapa orang akan selamat"; 2 ) " $2 / 3$ kemungkinan tidak ada orang yang selamat" akan diartikan menjadi "tidak ada orang yang selamat". Oleh karenanya, penggunaan kata 'tidak sama sekali' ataupun 'beberapa' menjadi faktor yang cukup penting dalam sebuah framing (Kühberger \& Tanner, 2010). Teori fuzzy-trace menjelaskan proses pengambilan keputusan terjadi melalui pertimbangan yang sederhana (Reyna \& Brainerd, 1991). Hal tersebut menunjukkan bahwa sebuah keputusan tidak didasari oleh proses komputasi tetapi lebih menggunakan pemikiran intuitif yang membuat sebuah pemikiran bekerja secara paralel daripada berseri serta bekerja dengan proses yang paling sederhana (Reyna, 2004).

Meskipun sama-sama membahas mengenai efek framing terhadap keputusan berisiko, kedua teori diatas memiliki beberapa perbedaan. Teori prospek menggunakan pendekatan tradisional yang menggunakan pendekatan kombinasi antara untung dan rugi dalam proses pembuatan keputusan sementara teori fuzzy-trace lebih menekankan pada proses kognitif dalam memproses informasi secara sederhana dan intuitif (Kühberger \& Tanner, 2010). Perbedaan kedua teori terlihat dari penggunaan 
zero complement atau penggunaan kata "tidak sama sekali". Zero complement akan efektif digunakan pada teori fuzzy trace dan tidak efektif pada teori prospek.

Persepsi untung dan rugi terhadap suatu keputusan erat kaitannya dengan bagaimana informasi disajikan. Framing menjadi salah satu faktor penting dalam penyajian informasi tersebut. Framing membuat informasi kesehatan dapat dilihat dari kacamata untung dan rugi sehingga berpotensi mengubah perilaku masyarakat saat menerima informasi (Rothman dkk., 1997). Beberapa penelitian ternyata gagal membuktikan adanya efek framing yang diberikan pada proses penelitian. Fagley \& Miller (1987) mencoba untuk melakukan penelitian yang sama dengan penelitian Tversky \& Kahneman (1981) sebagai pelopor penelitian mengenai risky choice framing, penelitian tersebut memiliki hasil akhir yang berbeda yang menunjukkan tidak adanya signifikansi pada efek framing. Perbedaan tersebut disebabkan karena beberapa faktor. Faktor pertama adalah adanya perbedaan partisipan. Partisipan dalam penelitian Fagley \& Miller adalah mahasiswa bisnis yang dianggap merepresentasikan populasi dengan kecenderungan menghindari resiko. Faktor kedua adalah penggunaan skenario masalah. Faktor ketiga adalah adanya perbedaan prosedural dalam penelitian. Kesimpulan ketiga ini didapat dari perbedaan efek framing pada partisipan dengan perintah dan yang tidak untuk menjelaskan rasionalitas mereka.

Penelitian lain yang menunjukkan hasil tidak signifikan pada pemberian framing adalah pada penelitian mengenai pekerjaan dan gaji. Pada penelitian tersebut partisipan memiliki perbedaan persepsi dimana sebagian partisipan menganggap situasi permasalahan sebagai hal yang netral sementara sebagian yang lain menganggap situasi tersebut sebagai ancaman (Highhouse \& Yüce, 1996). Situasi yang mengancam akan membuat seseorang enggan untuk menanggung resiko. Penelitian lain juga gagal membuktikan efek framing karena jumlah informasi yang diberikan pada responden cukup banyak sehingga efek framing menghilang (Schoorman dkk., 1994). Efek framing juga akan berkurang apabila seseorang acuh dengan permasalahan yang sedang dihadapi dan pada permasalahan yang tidak terlalu memerlukan proses pemikiran yang cukup mendalam (Igou \& Bless, 2007).

Meskipun beberapa penelitian menunjukkan hasil tidak signifikan pada efek framing, framing tetap menjadi salah satu faktor yang cukup berpengaruh karena memiliki kekuatan untuk mengubah interpretasi makna (Tversky \& Kahneman, 1981). Alasan itulah yang membuat peneliti ingin mengetahui dampak framing terhadap pembuatan keputusan dengan hipotesis awal bahwa risky choice framing memiliki efek positif terhadap pemilihan keputusan berisiko. Penelitian ini berusaha mereplikasi penelitian Kühberger \& Tanner (2010). Dalam penelitian tersebut, framing disajikan berdasarkan dua pendekatan yaitu pendekatan teori prospek dan teori fuzzy-trace. Dari beberapa jenis pendekatan framing, tidak semuanya memiliki efek yang signifikan. Hasil riset yang mereka lakukan diperkirakan dapat berubah mengingat penelitian ini dilakukan dalam konteks sosial dan budaya yang berbeda. Diharapkan penelitian ini dapat memberikan referensi lain mengenai topik pembuatan keputusan berisiko dan risky choice framing.

\section{Desain Penelitian}

\section{MET O D E}

Penelitian ini merupakan penelitian kuantitatif dengan menggunakan eksperimen sebagai metode pengambilan data. Jenis eksperimen yang digunakan adalah theory-directed experiment dimana penelitian mencoba untuk menguji kebenaran empiris dari sebuah teori (Neuman, 2014). Alasan pemilihan jenis eksperimen ini dikarenakan penelitian ini mencoba untuk meneliti efek risky choice 
framing terhadap pemilihan keputusan berisiko dengan menggunakan teori prospek dan teori fuzzytrace sebagai dasar penelitian.

\section{Partisipan}

Partisipan pada penelitian ini adalah seseorang dengan rentang umur 19-24 tahun. Pembatasan pada rentang umur dipilih karena setiap tahapan perkembangan, manusia akan memiliki intensitas pembuatan keputusan berisiko yang berbeda (Gardner \& Steinberg, 2005). Alasan tersebut menjadikan partisipan harus berada pada rentang umur yang sama. Partisipan dalam penelitian ini paling tidak sedang menjalani perkuliahan atau sudah lulus. Alasan ini dibuat demi memastikan partisipan mampu memahami skenario masalah yang disajikan.

Sampel minimun yang diperlukan dalam penelitian ini adalah 75 partisipan. Angka ini didapat berdasarkan penghitungan besaran efek (cohen's $d$ ) 0,32 dari penelitian acuan milik Kühberger \& Tanner (2010) menggunakan aplikasi PANGEA (Westfall, 2016). Partisipan direkrut menggunakan teknik conveinence sampling yang merupakan bagian dari non-probability sampling. Teknik ini adalah teknik yang banyak digunakan dalam penelitian psikologi (Howitt \& Cramer, 2011). Peneliti akan mengajak partisipan yang dekat dengan peneliti sehingga memberikan kemudahan akses. Partisipan sebelumnya telah menyetujui informed consent untuk ikut berpartisipasi dalam penelitian.

Total partisipan dalam penelitian ini adalah 121 orang $\left(M_{\text {usia }}=21 ; S D_{\text {usia }}=1,08 ; 73,6\right.$ persen perempuan). Mayoritas partisipan merupakan mahasiswa dengan persentase 96,8\% dan sisanya bukan mahasiswa. Latar belakang pendidikan partisipan yang paling mendominasi adalah psikologi $(42,4 \%)$, sosiologi $(10,4 \%)$, dan farmasi $(9,6 \%)$.

\section{Pengukuran}

Penelitian ini menggunakan metode eksperimen sebagai metode riset. Desain eksperimen yang digunakan dalam penelitian ini adalah mixed factorial design. Pemilihan factorial design karena penelitian menggunakan lebih dari 2 variabel independen (Morling, 2017). Variabel independen dalam penelitian ini adalah positive framing dan negative framing, skenario, dan tipe framing. Variabel independen ini adalah bagian dari perlakuan eksperimen. Dari variabel-variabel tersebut terbentuk desain eksperimen 2 (framing: positif vs negatif) x 3 (tipe framing: klasik, teori prospek, dan teori fuzzy trace) $x 4$ (skenario masalah: penyakit ginjal pada ikan, kontaminasi air, tanaman rekayasa genetik, dan emisi karbon dioksida). Mixed method dipilih dengan alasan penelitian menggunakan desain betweensubject dan within-subject (Morling, 2017). Variabel yang termasuk ke dalam between-subject adalah framing dan tipe framing sementara variabel yang termasuk ke dalam within-subject adalah skenario masalah.

Sebelum dilakukan eksperimen, peneliti mengukur validitas dan reabilitas skenario yang akan digunakan pada eksperimen. Validitas diukur menggunakan validitas linguistik dan validitas konten. Validitas konten diukur dengan content validity index (CVI) dan cognitive interviewing. Hasil pengukuran CVI pada skenario adalah 0,6. Aspek yang diukur dalam cognitive interviewing adalah pemahaman partisipan terhadap instruksi pengerjaan skenario dan skenario. Pemahaman terhadap skenario tercermin dalam kemudahan partisipan memahami arti kata yang digunakan serta tidak adanya ambiguitas dalam setiap kalimat. Cognitive interviewing diisi oleh dua orang yang memiliki kriteria sebagai populasi dengan rata-rata waktu pengerjaan yaitu 10-15 menit. Meskipun sebagian besar skenario bisa dipahami, namun peneliti mendapatkan beberapa masukan untuk mengubah penggunaan beberapa kata yang sulit dipahami. Peneliti juga menguji reabilitas menggunakan uji reliabilitas McDonald's $\omega$ dengan program Jamovi. Reabilitas digunakan untuk mengukur empat buah skenario cerita yang digunakan pada eksperimen. Berdasarkan hasil pengujian, keseluruhan skenario memiliki 
nilai reliabilitas McDonald's $\omega$ sebesar 0,709. Nilai ini berada pada rentang angka yang cukup tinggi sehingga peneliti menyertakan semua skenario cerita dalam analisis data.

Proses eksperimen dilakukan sesuai dengan desain penelitian yang sebelumnya dilakukan oleh Kühberger \& Tanner (2010). Penelitian diawali dari pembagian partisipan ke dalam tiga kelompok yang berbeda berdasarkan perlakuan tipe framing. Perlakuan tipe framing pada setiap kelompok dijelakan pada tabel 1. Setiap kelompok akan mendapatkan empat buah skenario yang sama. Pada tiap skenario terdapat empat buah opsi pilihan jawaban yang telah diberikan framing sesuai kelompok masingmasing. Responden diminta untuk memilih pilihan diantara opsi berisiko dan opsi tidak berisiko. Sebelum dilakukan olah data peneliti melakukan uji asumsi yang terdiri dari uji normalitas, homokesdastisitas, dan independensi variabel. Namun, peneliti tidak perlu melakukan uji indepedensi residual karena setiap responden dalam kelompok eksperimen merupakan responden yang berbeda.

Tabel 1. Perlakuan pada Eksperimen

\begin{tabular}{cccc}
\hline \multirow{2}{*}{$\begin{array}{c}\text { Kelompok } \\
\text { Eksperimen }\end{array}$} & Opsi & \multicolumn{2}{c}{ Framing } \\
\cline { 3 - 4 } & & Positif & Negatif \\
\hline \multirow{2}{*}{1} & Tidak Berisiko & $(\mathrm{sG})$ & $(\mathrm{sL})$ \\
& Berisiko & $(\mathrm{r}, \mathrm{G})$ & $(\mathrm{r} \sim \mathrm{L})(\mathrm{r}, \mathrm{L})$ \\
2 & Tidak Berisiko & $(\mathrm{r} \sim \mathrm{G})$ & $(\mathrm{sL})$ \\
& Berisiko & $(\mathrm{r}, \mathrm{G})$ & $(\mathrm{r}, \mathrm{L})$ \\
& Tidak Berisiko & $(\mathrm{sG})$ & $(\mathrm{sL})$ \\
& Berisiko & $(\mathrm{r} \sim \mathrm{G})$ & $(\mathrm{r} \sim \mathrm{L})$ \\
\hline
\end{tabular}

Uji normalitas dalam penelitian ini dilakukan dengan menggunakan analisis skewness dan kurtosis. Hasil uji normalitas pada skenario satu menunjukkan skor skewness -1.17 dan skor kurtosis -.644, skenario dua menunjukkan skor skewness -1.13 dan skor kurtosis -.733, skenario tiga menunjukkan skor skewness -.574 dan skor kurtosis -.1.70, dan skenario empat menunjukkan skor skewness -.464 dan skor kurtosis -1.82. Dari skor tersebut dapat disimpulkan apabila data pada penelitian ini adalah tidak normal. Meskipun data penelitian tidak normal namun penulis tetap melakukan uji ANOVA karena ANOVA tetap reliabel terhadap data yang tidak normal (Blanca dkk., 2017).

Uji homogenitas varian dilakukan menggunakan lavene's test untuk mengukur hipotesis nol serta kesamaan variansi antar kelompok (Field, 2010). Uji ANOVA mengharuskan data memenuhi syarat homoskedastisitas. Hasil lavene's test pada penelitian ini menunjukkan apabila skenario empat memiliki nilai $(\mathrm{p}=.096)$ sehingga memenuhi syarat homoskedastisitas. Hasil uji asumsi pada skenario satu, skenario dua, dan skenario tiga menunjukkan angka yang sama yaitu $(\mathrm{p}<.001)$ sehingga perlu dilakukan uji Welch. Dari hasil uji tersebut hanya skenario tiga yang menunjukkan perubahan nilai yaitu $(\mathrm{p}=.024)$ pada welch test. Meskipun asumsi homoskesdastisitas tidak terpenuhi namun karena jumlah partisipan dalam penelitian ini sama maka peneliti tetap menggunakan uji ANOVA (Field \& Miles, 2010).

Analisa data akan dilakukan untuk mengetahui variasi perlakuan pada setiap kelompok eksperimen (Navarro \& Foxcroft, 2019). Analisa data pertama yang dilakukan adalah analisa statistik deskriptif. 
Analisa data kedua menggunakan Mixed Repeated Measure ANOVA menggunakan aplikasi Jamovi 1.2.27. Pemilihan teknik tersebut karena teknik analisis bisa dilakukan untuk menganalisa within-subject dan between-subject.

\section{HAS IL PENELITIAN}

Penelitian melibatkan 121 partisipan yang dibagi ke dalam 3 kelompok perlakuan. Kelompok pertama terdiri dari 43 partisipan, kelompok kedua terdiri dari 38 partisipan, dan kelompok ketiga terdiri dari 40 partisipan. Variabel keputusan berisiko merupakan variabel dependen yang dihitung melalui pilihan pada opsi yang diberikan oleh responden. Dari tiga kelompok eksperimen yang ada, kelompok dua merupakan kelompok dengan nilai rata-rata yang paling tinggi, diikuti dengan kelompok satu, dan kelompok tiga.

Tabel 2. Nilai Rata-rata

\begin{tabular}{cccc}
\hline & Kelompok & Perlakuan & $\begin{array}{c}\text { Pilihan Keputusan } \\
\text { Berisiko }\end{array}$ \\
\hline $\begin{array}{c}\text { Rata- } \\
\text { Rata }\end{array}$ & 1 & Teori Klasik & 0.750 \\
& 2 & $\begin{array}{c}\text { Teori Prospek } \\
\text { Teori Fuzzy- } \\
\text { Trace }\end{array}$ & 0.805 \\
& 3 & & 0.575 \\
\hline
\end{tabular}

Hipotesis awal penelitian yaitu efek risky choice framing terhadap pembuatan keputusan berisiko ditolak karena efek framing dilaporkan tidak signifikan terhadap pembuatan keputusan berisiko $\left(F(12,333)=0,782 ; p=0,669 ; \eta^{2}=0,011\right)$. Perlakuan framing positif dan framing negatif memiliki nilai signifikan $\left(\mathrm{F}(2,111)=92,98, \mathrm{p}<.001 ; \eta^{2}=.196\right)$. Namun, apabila dilihat nilai estimated marginal means pembuatan keputusan berisiko pada framing negatif dan pembuatan keputusan berisiko pada framing positif, keduanya hampir memiliki kesamaan nilai.

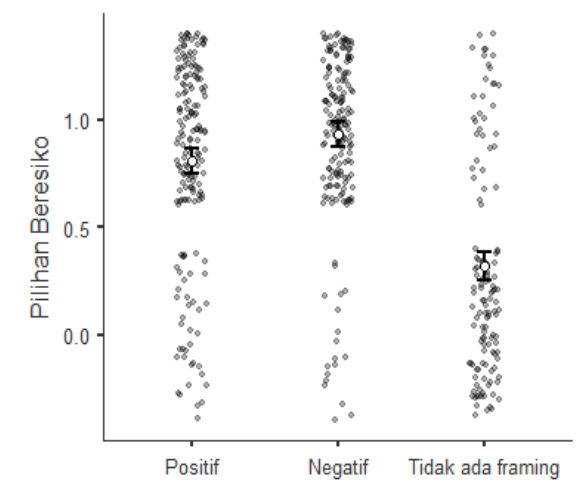

Gambar 1. Estimated Marginal Means Framing

Efek utama skenario menunjukkan adanya signifikansi terhadap pilihan responden dalam membuat keputusan berisiko $\left(F(3,333)=2.755 ; \mathrm{p}<0.043 ; \eta^{2}=.010\right)$. Hal ini berakibat apabila efek skenario dihilangkan maka tingkat pemilihan keputusan berisiko pada responden akan berbeda. Hubungan interaksi antara skenario $\mathrm{x}$ framing positif dan framing negatif memiliki nilai $(\mathrm{F}(6,333)=.955 ; \mathrm{p}=.456$; 
$\left.\eta^{2}=.007\right)$ mengindikasikan apabila nilai framing positif dan negatif pada tiap skenario tidak menunjukkan adanya variasi.

Efek utama tiga kelompok eksperimen pada penelitian menunjukkan tidak adanya efek signifikan $\left(F(2,111)=1.54 ; p<0.219 ; \eta^{2}=.003\right)$ yang mengindikasikan apabila pemilihan keputusan berisiko pada kelompok satu, kelompok dua, dan kelompok tiga tidak menunjukkan adanya perbedaan. Apabila dilihat pada plot estimated marginal means ketiga titik yang merepresentasikan ketiga kelompok saling tumpang tindih artinya ketiga kelompok hampir memiliki kesamaan nilai. Interaksi antara kelompok $\mathrm{x}$ framing positif dan negatif menunjukkan tidak adanya variasi $\left(F(4,111)=1,72 ; p=.15 ; \eta^{2}=.007\right)$.

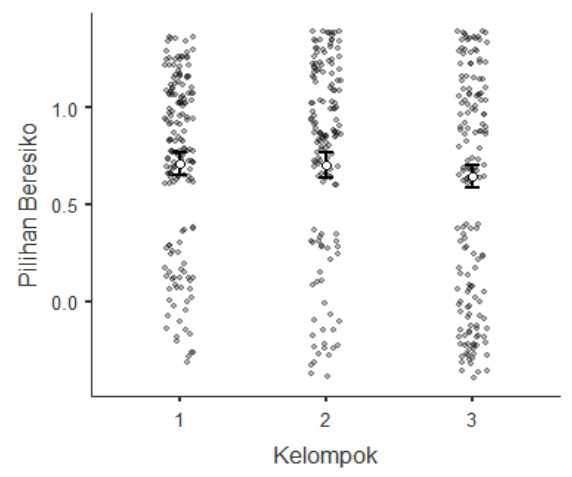

Gambar 2. Estimated Marginal Means Kelompok

Peneliti juga melakukan post-hoc test pada efek kelompok untuk mengetahui perbedaan intensitas responden dalam pembuatan keputusan berisiko menggunakan holm untuk mengkoreksi nilai P. Hasil menunjukkan jika hampir tidak ada perbedaan intensitas pembuatan keputusan berisiko pada ketiga kelompok. Terdapat sedikit perbedaan intensitas pengambilan keputusan berisiko antara kelompok pertama $(\mathrm{M}=.767, \mathrm{SD}=.427)$ dengan kelompok kedua $(\mathrm{M}=.805, \mathrm{SD}=.401)(\mathrm{t}(111)=-.183, \mathrm{P}=.855)$. Namun, antara kelompok kedua dan ketiga $(\mathrm{M}=.575, \mathrm{SD}=.501)(\mathrm{t}(111)=1,3, \mathrm{P}=.393)$ tidak ada perbedaan yang berarti.

\section{I S K U S I}

Efek variabel risky choice framing tidak memiliki pengaruh terhadap pembuatan keputusan berisiko. Hal ini dilihat dari hasil olah data pada efek perlakuan yang diberikan pada proses eksperimen terhadap pembuatan keputusan berisiko. Penelitian ini tidak melakukan randomisasi sehingga peneliti kurang bisa memastikan apabila hasil penelitian tersebut benar-benar merupakan efek dari manipulasi perlakuan yang diberikan pada proses eksperimen. Pembagian responden pada tiap kelompok eksperimen hanya didasarkan oleh keputusan peneliti tanpa dilakukan matching dan mempertimbangkan proporsi demografi.

Responden dalam penelitian ini memiliki jumlah yang hampir sama dalam memilih keputusan berisiko pada framing negatif ataupun pada framing positif. Apabila melihat hasil penelitian sebelumnya yang dilakukan oleh Kahneman \& Tversky (1979) dapat disimpulkan apabila seseorang cenderung membuat keputusan berisiko pada framing negatif. Hasil penelitian ini berbeda dari penelitian sebelumnya. Hal ini terjadi karena setiap responden kemungkinan memiliki perbedaan penafsiran terhadap kondisi yang menguntungkan dan kondisi yang merugikan. Perbedaan penafsiran dapat disebabkan karena berbagai 
sebab seperti suasana hati yang mampu mengubah situasi yang menguntungkan menjadi terkesan merugikan dan sebaliknya (Schwarz, 1990). Faktor kedua adalah optimisme dan pesimisme dalam memandang masalah dalam sebuah opsi (Scheier \& Carver, 1985). Misalnya dalam skenario pertama apabila seseorang pesimis oleh keberadaan vaksin maka kemampuan vaksin untuk menyelamatkan nyawa seseorang tidak dilihat sebagai keadaan yang menguntungkan. Ketidak mampuan dalam melihat suatu keadaan sebagai suatu hal yang merugikan atau menguntungkan juga disebabkan oleh perbedaan pengalaman dan pengetahuan yang dimiliki responden (Rothman dkk., 1997).

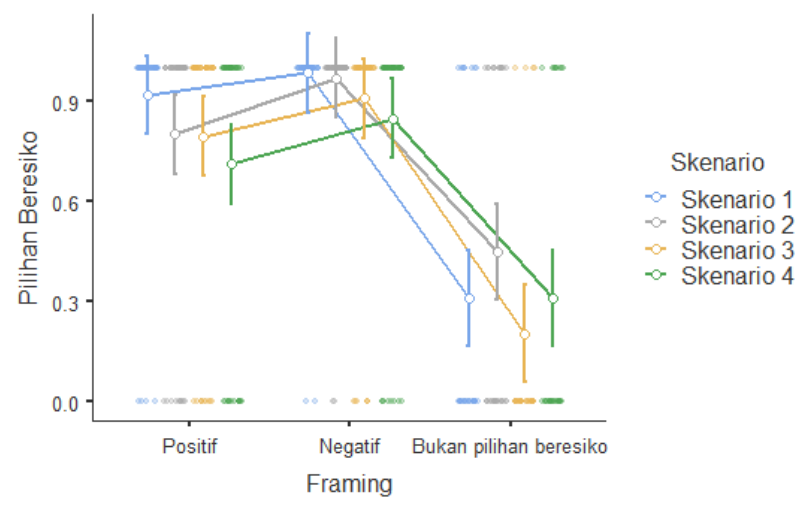

Gambar 3. Estimated Marginal Means Skenario x Framing

Hubungan antara skenario dan framing pada nilai estimated marginal means terlihat apabila skenario empat konsisten menjadi skenario yang memiliki nilai rata-rata paling rendah dibandingkan skenario yang lain. Wang (1996) menyatakan apabila efek framing dalam mempengaruhi preferensi resiko disebabkan oleh intensitas resiko yang ditimbulkan oleh suatu masalah, konten, dan konteks permasalahan suatu keputusan. Skenario empat memiliki konteks permasalahan yang cukup berbeda dibanding skenario yang lain yaitu mengenai pemanasan global. Terdapat kemungkinan jika tidak semua orang memiliki persepsi yang sama mengenai tingkat kegawat-daruratan akan masalah yang disajikan peneliti maka beberapa kelompok akan tetap tidak percaya dengan adanya pemanasan global (Fischer, 2019). Skenario empat memiliki hasil yang berbanding terbalik dengan skenario satu. Skenario satu memiliki nilai rata-rata paling tinggi pada framing positif dan framing negatif. Berbeda dengan skenario empat, skenario satu membahas mengenai masalah kesehatan manusia yang sangat mudah dipahami efeknya oleh semua orang (Kühberger, 1998). Hal ini membuat framing pada skenario satu memiliki efek yang lebih kuat pada pembuatan keputusan. 


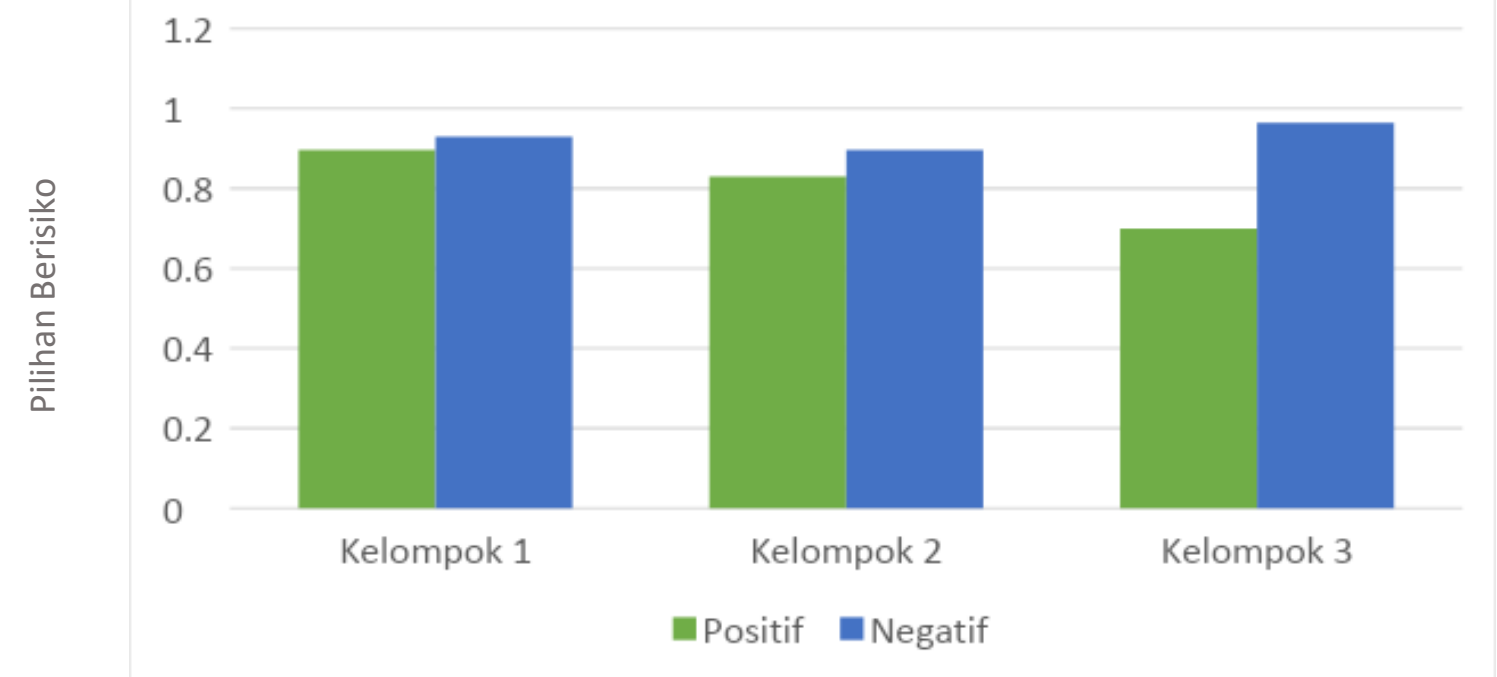

Gambar 4. Estimated Marginal Means Kelompok x Framing Positif dan negatif

Eksperimen dibagi ke dalam tiga kelompok berdasarkan perbedaan perlakuan yang didapatkan. Kelompok satu mengacu pada teori klasik, kelompok kedua mengacu pada teori prospek, dan kelompok tiga mengacu pada teori fuzzy-trace. Sebagian besar kelompok menunjukkan adanya kesamaan hasil sehingga tidak terdapat variasi hasil pada tiga kelompok eksperimen, namun berdasarkan nilai estimated marginal means ketiga kelompok menunjukkan perbedaan selisih nilai rata-rata antara framing positif dan framing negatif. Kelompok tiga sebagai kelompok yang mendapat perlakuan teori fuzzy-trace memiliki perbedaan nilai rata-rata estimated marginal means yang paling besar antara pilihan berisiko pada framing positif dan pilihan berisiko pada framing negatif sehingga memberikan kemungkinan apabila perlakuan yang diberikan pada kelompok ini memiliki pengaruh yang paling besar diantara kelompok yang lain. Reyna \& Brainerd (1991) berpendapat apabila teori fuzzy trace menjelaskan bagaimana seseorang memproses informasi dengan cara mereduksi semua informasi yang ada termasuk informasi numerik menjadi informasi yang bersifat kualitatif, misalnya pada opsi eksperimen "Apabila keputusan untuk melepas ikan dilakukan, terdapat 1/3 kemungkinan tidak ada satupun dari 12 ikan akan mati" akan diartikan menjadi "Apabila keputusan untuk melepas ikan dilakukan, tidak satupun ikan akan mati”. Hal ini membuat keputusan dibuat secara cepat dan intuitif dengan mengabaikan keterbatasan kognitif yang dimiliki seseorang. Berbeda dengan kelompok dua yang menggunakan pendekatan untung dan rugi dalam menjelaskan proses pemilihan keputusan berisiko (Kühberger \& Tanner, 2010). Persepsi untung dan rugi sangat dipengaruhi oleh pengetahuan yang dimiliki oleh seseorang. Perbedaan pengetahuan yang dimiliki akan menimbulkan perbedaan makna terhadap sebuah opsi. Masalah kesehatan akan lebih mudah dipahami karena semua orang akan memiliki kesamaan persepsi mengenai efek negatif dan efek positif yang dihasilkan pada masalah kesehatan (Kühberger, 1998).

Pada kelompok satu, perbedaan selisih nilai rata-rata antara keputusan berisiko yang dibuat dalam framing positif dan framing negatif sangat kecil. Hal ini dikarenakan kelompok satu menerima informasi paling banyak diantara kelompok lain sehingga berpotensi menghilangkan efek perlakuan eksperimen yang telah diberikan kepada responden (Schoorman dkk., 1994). Misalnya, apabila kelompok lain dalam opsi yang sama hanya menerima informasi "Apabila vaksin diberikan, akan ada 1/3 kemungkinan kesehatan kesemua 720 anak akan selamat" maka kelompok satu mendapatkan kuantitas informasi yang lebih banyak berupa "Apabila vaksin diberikan, akan ada 1/3 kemungkinan 
kesehatan kesemua 720 anak akan selamat dan 2/3 kemungkinan bahwa tidak ada satupun dari kesehatan mereka yang akan selamat." Peningkatan kuantitas informasi membuat seseorang tidak terpengaruh oleh adanya framing.

Skenario adalah salah satu perlakuan penting dalam proses eksperimen untuk menunjukkan pemahaman yang sama pada responden mengenai kondisi untung dan rugi pada sebuah masalah. Topik skenario yang susah dipahami akan membuat responden membuat keputusan bukan berdasarkan informasi yang disajikan namun akan mencari informasi dari sumber yang lain (Wang, 1996). Dalam keadaan seperti ini, kemungkinan partisipan untuk memilih keputusan berisiko pada framing positif dan framing negatif akan menjadi setara.

\section{S I M P U L A N}

Penelitian ini menyimpulkan apabila risky choice framing tidak memiliki efek terhadap pilihan keputusan berisiko ditandai dengan adanya nilai tidak signifikan pada kedua variabel. Kesimpulan ini memiliki hasil yang berbeda dari penelitian yang dijadikan sebagai acuan yaitu penelitian milik Kühberger \& Tanner (2010). Kegagalan penelitian dalam membuktikan efek risky choice framing tidak serta merta diartikan apabila framing tidak memiliki pengaruh terhadap pembuatan keputusan berisiko. Namun, kegagalan ini membuktikan apabila kemampuan seseorang dalam mempersepsi suatu masalah cukup berpengaruh dalam pembuatan keputusan berisiko. Persepsi ini dipengaruhi oleh konteks suatu masalah yang disebabkan oleh skenario yang digunakan pada proses eksperimen. Topik yang digunakan pada proses eksperimen dinilai susah dipahami oleh responden, seperti penyakit ginjal proliferatif pada ikan, tanaman rekayasa yang menurunkan eksistensi jumlah serangga, ataupun pemanasan global. Masalah-masalah tersebut sangat jarang ditemui pada kehidupan sehari-hari sehingga seseorang akan merasa kesulitan untuk memahami untung dan rugi dari sebuah masalah yang ada.

Dari penjelasan tersebut diharapkan penelitian selanjutnya lebih mempertimbangkan topik permasalahan dalam perlakuan skenario yang digunakan pada proses eksperimen. Artinya, di kemudian hari peneliti juga diharapkan lebih mempertimbangkan pengetahuan yang dimiliki oleh responden dengan cara membatasi latar belakang responden.

Afida Sabrina Syifa tidak bekerja, menjadi konsultan, memiliki saham, atau menerima dana dari perusahaan atau organisasi manapun yang mungkin akan mengambil untung dari diterbitkannya naskah ini.

\section{PUSTAKA ACUAN}

Albert, S., \& Duffy. (2012). Differences in risk aversion between young and older adults. Neuroscience and Neuroeconomics, 2012(1), 3. https://doi.org/10.2147/nan.s27184

Anderson, L. R., \& Mellor, J. M. (2008). Predicting health behaviors with an experimental measure of risk preference. Journal of Health Economics, 27(5), 1260-1274.

Blanca, M. J., Alarcón, R., Arnau, J., Bono, R., \& Bendayan, R. (2017). Non-normal data: Is ANOVA still a valid option? Psicothema, 29(4), 552-557. https://doi.org/10.7334/psicothema2016.383

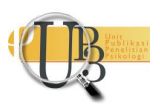


Fagley, N. S., \& Miller, P. M. (1987). The Effects of Decision Framing on Choice of Risky vs Certain Options. Organizational Behaviour and Human Decision Processes, 39, 264-277.

Fagley, N. S., \& Miller, P. M. (1990). The Effect of Framing on Choice. Personality and Social Psychology Bulletin, 16(3), 496-510. https://doi.org/10.1177/0146167290163008

Field, A. (2010). Discovering Statistics Using IBM SPSS Statistics, 4th Edition (M. Carmichael (ed.); 3rd ed.). SAGE Publications Inc.

Field, A., \& Miles, J. (2010). Discovering Statistics Using SAS. SAGE Publications Inc.

Fischer, F. (2019). Knowledge politics and post-truth in climate denial: on the social construction of $\begin{array}{lllll}\text { alternative facts. } & \text { Critical } & \text { Policy } & \text { Studies, } & 133(2),\end{array}$ https://doi.org/10.1080/19460171.2019.1602067

Fisher, S. A. (2020). Meaning and framing: the semantic implications of psychological framing effects. Inquiry, 1-24. https://doi.org/10.1080/0020174X.2020.1810115

Gardner, M., \& Steinberg, L. (2005). Peer Influence on Risk Taking, Risk Preference, and Risky Decision Making in Adolescence and Adulthood: An Experimental Study. https://doi.org/10.1037/00121649.41.4.625

Grichnik, D. (2008). Risky choices in new venture decisions - Experimental evidence from Germany and the United States. Journal of International Entrepreneurship, 6(1), 22-47. https://doi.org/10.1007/s10843-008-0019-5

Hardisty, D. J., Johnson, E. J., \& Weber, E. U. (2010). A dirty word or a dirty world? attribute framing, political affiliation, and query theory. Psychological Science, 21(1), 86-92. https://doi.org/10.1177/0956797609355572

Heilman, R. M., \& Miclea, M. (2016). Risk Seeking Preferences: An Investigation of Framing Effects across Decisional Domains. Cognition, Brain, Behavior: An Interdisciplinary Journal, 20(1), 1-16.

Hellinger, F. J. (1989). Expected utility theory and risky choices with health outcomes. Medical Care, 27(3), 273-279. https://doi.org/10.1097/00005650-198903000-00005

Highhouse, S., \& Yüce, P. (1996). Perspectives, perceptions, and risk-taking behavior. Organizational Behavior and Human Decision Processes, 65(2), 159-167. https://doi.org/10.1006/obhd.1996.0014

Howitt, D., \& Cramer, D. (2011). Introduction to research methods in psychology (3 ed.). Pearson Education.

Igou, E. R., \& Bless, H. (2007). On undesirable consequences of thinking: framing effects as a function of substantive processing. Journal of Behavioral Decision Making, 20(2), 125-142. https://doi.org/10.1002/bdm.543

Kahneman, D. (1991). JUDGMENT AND DECISION MAKING: A Personal View. PSYCHOLOGICAL SCIENCE, 2(3), 142-145.

Kahneman, D., \& Tversky, A. (1979). PROSPECT THEORY: AN ANALYSIS OF DECISION UNDER RISK. Econometrica, 47(2), 263-291. 
Krishnamurthy, P., Carter, P., \& Blair, E. (2001). Attribute Framing and Goal Framing Effects in Health Decisions. Organizational Behavior and Human Decision Processes, 85(2), 382-399. https://doi.org/10.1006/obhd.2001.2962

Kühberger, A. (1998). The Influence of Framing on Risky Decisions: A Meta-analysis. 75(1), 23-55. https://doi.org/10.1006/obhd.1998.2781

Kühberger, A., \& Tanner, C. (2010). Risky choice framing: Task versions and a comparison of prospect theory and fuzzy-trace theory. In Journal of Behavioral Decision Making (Vol. 23, Nomor 3, hal. 314329). John Wiley and Sons Ltd. https://doi.org/10.1002/bdm.656

Kusev, P., \& van Schaik, P. (2011). Preferences under risk: Content-dependent behavior and psychological processing. In Frontiers in Psychology (Vol. 2, Nomor NOV). Front Psychol. https://doi.org/10.3389/fpsyg.2011.00269

Levin, I. P., Schneider, S. L., \& Gaeth, G. J. (1998). All Frames Are Not Created Equal: A Typology and Critical Analysis of Framing Effects. In ORGANIZATIONAL BEHAVIOR AND HUMAN DECISION PROCESSES (Vol. 76, Nomor 2).

Linde, J., \& Sonnemans, J. (2012). Social comparison and risky choices. Journal of Risk and Uncertainty, 44(1), 45-72. https://doi.org/10.1007/s11166-011-9135-z

Lusk, J. L., \& Coble, K. H. (2005). Risk Perceptions, Risk Preference, and Acceptance of Risky Food. American Journal of Agricultural Economics, 87(2), 393-405. https://doi.org/10.1111/j.14678276.2005.00730.x

Morling, B. (2017). Research methods in psychology : evaluating a world of information (3 ed.). W. W. Norton \& Company.

Navarro, D., \& Foxcroft, D. (2019). Learning statistics with jamovi: a tutorial for psychology students and other beginners. $10.24384 / \mathrm{hgc} 3-7 \mathrm{p} 15$

Neuman, W. L. (2014). Social research methods: Qualitative and quantitative approaches (7 ed.). Pearson Education.

Park, N. Y. (2016). Domain-specific risk preference and cognitive ability. Economics Letters, 141, 1-4.

Peng, J., Li, H., Miao, D., Feng, X., \& Xiao, W. (2013). Five different types of framing effects in medical situation: A preliminary exploration. Iranian Red Crescent Medical Journal, 15(2), 161. https://doi.org/10.5812/ircmj.8469

Repetto, C., Sek'scí, K., Sek'scí, S., Kusev, P., Purser, H., Heilman, R. M., Cooke, A. J., Schaik, P. Van, Baranova, V., Martin, R., \& Ayton, P. (2017). Understanding Risky Behavior: The Influence of Cognitive, Emotional and Hormonal Factors on Decision-Making under Risk. Frontiers in Psychology / www.frontiersin.org, 8, 102. https://doi.org/10.3389/fpsyg.2017.00102

Reyna, V. F. (2004). How People Make Decisions That Involve Risk. Current Directions in Psychological Science, 13(2), 60-66. https://doi.org/10.1111/j.0963-7214.2004.00275.x

Reyna, V. F., \& Brainerd, C. J. (1991). Fuzzy-trace theory and framing effects in choice: Gist extraction, truncation, and conversion. Journal of Behavioral Decision Making, 4(4), 249-262. https://doi.org/10.1002/bdm.3960040403 
Rothman, A. J., Salovey, P., Bedell, B., Cioffi, D., Dertweiler, J., Lemm, K., Moyer, A., Wegener, D., \& Zullo, J. (1997). Shaping Perceptions to Motivate Healthy Behavior: The Role of Message Framing. In Psychological Bulletin Copyright (Vol. 121, Nomor 1). Weinstein.

Scheier, M. F., \& Carver, C. S. (1985). Optimism, coping, and health: Assessment and implications of generalized outcome expectancies. Health Psychology, 4(3), 219-247. https://doi.org/10.1037//0278-6133.4.3.219

Schoorman, F. D., Mayer, R. C., Douglas, C. A., \& Hetrick, C. T. (1994). Escalation of Commitment and the Framing Effect: An Empirical Investigation. Journal of Applied Social Psychology, 24(6), 509-528. https://doi.org/10.1111/j.1559-1816.1994.tb00596.x

Schwarz, N. (1990). Feelings as information: Informational and motivational functions of affective states. In E. T. Higgins \& R. Sorrentino (Ed.), Handbook of Motivation and Cognition. Guilford Press. https://psycnet.apa.org/record/1990-98254-015

Steinberg, L. (2006). Risk taking in adolescence: What changes, and why? Annals of the New York Academy of Sciences, 1021(1), 51-58. https://doi.org/10.1196/annals.1308.005

Tomova, L., \& Pessoa, L. (2018). Information about peer choices shapes human risky decision-making. Scientific Reports, 8.

Tversky, A., \& Kahneman, D. (1981). The Framing of Decisions and the Psychology of Choice. science, 211, 452-458. www.sciencemag.org

Wang, X. T. (1996). Framing Effects 1 Organizational Behavior and Human Decision Processes Vol Framing Effects: Dynamics and Task Domains (Vol. 68, Nomor 2).

Westfall, J. (2016). PANGEA: Power ANalysis for GEneral Anova designs. http://jakewestfall.org/pangea/ 